\title{
Model Simulasi Peningkatan Ternak Sapi Induk Pola Gaduhan terhadap Curahan Tenaga Kerja: Studi Kasus di Kecamatan Amanuban Selatan, Propinsi Nusa Tenggara Timur
}

\author{
Stefanus Amalo ${ }^{1,2}$, Budi Hartono ${ }^{3}$ dan Hari Dwi Utami ${ }^{3}$ \\ ${ }^{1}$ Mahasiswa Pasca Sarjana Fakultas Peternakan Universitas Brawijaya \\ ${ }^{2}$ Dinas Peternakan Provinsi Nusa Tenggara Timur, Jl. Veteran - Kelapa Lima, Kupang, \\ Nusa Tenggara Timur \\ ${ }^{3}$ Program Pasca Sarjana Fakultas Peternakan Universitas Brawijaya \\ E-mail: steven.amalo@yahoo.co.id
}

\begin{abstract}
ABSTRAK
Penelitian dilakukan di Kecamatan Amanuban Selatan, Propinsi Nusa Tenggara Timur. Penelitian bertujuan untuk menganalisis curahan tenaga kerja pada usaha sapi potong dan usahatani non sapi potong pola gaduhan dan menganalisis model simulasi peningkatan jumlah ternak sapi induk. Sampel diperoleh sebanyak 117 responden yang dikumpulkan dengan metode wawancara menggunakan kuisioner terstruktur. Analisis data menggunakan metode Two Stage Least Square (2SLS) dan simulasi model dengan program Aplikasi SAS 9.1. Hasil diperoleh curahan tenaga kerja rumah tangga pada usaha sapi potong adalah 195,24 JKSP/tahun dan curahan tenaga kerja usahatani non sapi potong sebesar 481,03 JKSP/tahun. Simulasi peningkatan jumlah ternak sapi induk sebesar $50 \%$ dapat meningkatkan curahan tenaga kerja rumahtangga pada usaha sapi potong, meningkatkan produksi usaha sapi potong dan meningkatkan surplus usaha sapi potong.
\end{abstract}

Kata kunci : ekonomi rumah tangga, pola gaduhan, sapi potong, alokasi waktu, keuntungan

\section{Model of Simulation in Cow Contract Farming Pattern toward Labour Allocation: Case Study at South Amanuban Sub District, East Nusa Tenggara}

\begin{abstract}
Research was carried out on South Amanuban Sub District, East Nusa Tenggara. The objective of this study was at analyse labour allocation in raising beef cattle and non beef cattle farming from contract farming pattern, and to determine simulation model for cow number enhancement. Data were collected by interview method using structured questionaire. In total, 117 respondents were obtained by purposive sampling method. Data were analysed using Two Stage Least Square (2SLS) method and simulation analysis with application of SAS 9.1 program. Result showed that households' labour allocation was 195.24 MLHE/year on beef cattle farming and 481.03 MLHE/year for non beef cattle farming. Simulation model indicated $50 \%$ increased of cattle number resulted in improving household time devoted on beef cattle farming, production as well as profit of raising beef cattle.
\end{abstract}

Key words: labour household, contract farming pattern, beef cattle, time allocation, profit 


\section{PENDAHULUAN}

Kemitraan dengan pola penggaduhan ternak sapi potong yang dilaksanakan di Kecamatan Amanuban Selatan, yakni masyarakat tani sebagai plasma dan Dinas Peternakan sebagai stakeholder melakukan hubungan timbal balik yang saling menguntungkan melalui hubungan hukum yang dilakukan berdasarkan penandatanganan kontrak penggaduhan sapi potong (sapi Bali). Masa kontrak penggaduhan ternak sapi potong belangsung (5) lima tahun dengan salah satu perjanjian yakni stakeholder memberikan ternak sapi betina bibit sebanyak 2 (dua) ekor kepada petani dan petani plasma mengembalikan turunannya sebanyak 3 (tiga) ekor kepada Dinas Peternakan Propinsi (Anonim 2010), sehingga menimbulkan minat petani ternak untuk memiliki ternak gaduhan.

Upaya pengembangan ternak sapi potong oleh petani memerlukan pengerahan berbagai kemampuan untuk memanfaatkan fungsi produksi yang ada (Soekartawi et al., 1986), petani dalam mempengaruhi produksinya dilakukan dengan memanfaatkan sumberdaya yang terbatas diantaranya penggunaan dan pemanfaatan tenaga kerja, bahkan mengkombinasikan berbagai fungsi produksi untuk mencapai tujuannya. Setiap keputusan yang dilakukan oleh petani ternak akan selalu bermuara pada peningkatan ekonomi rumahtangganya.

Berdasarkan fenomena diatas maka penelitian ini secara umum bertujuan untuk untuk : (1) Menganalisis curahan tenaga kerja usaha sapi potong dan usahatani non sapi potong rumahtangga peternak sapi potong pola gaduhan (2) Menganalisis model pengembangan jumlah sapi induk pola gaduhan.

\section{METODE PENELITIAN}

\section{Lokasi dan Waktu Penelitian}

Lokasi penelitian diKecamatan Amanuban Selatan, Kabupaten Timor Tengah Selatan, Provinsi Nusa Tenggara
Timur, dipilihnya wilayah penelitian dengan pertimbangan sebagai salah satu sentra pembibitan sapi potong di kabupaten Timor Tengan Selatan, pernah menjadi lokasi proyek kerjasama antara Pemerintah Daerah Nusa Tenggara Timur dengan Australia, untuk pembibitan ternak sapi potong, serta adanya keseragaman masyarakat didaerah yang mempunyai mata pencaharian yang hampir sama yaitu sebagai petani sekaligus peternak, yang terintegrasi dengan sistim pengembangan ternak melalui pola gaduhan, pengumpulan data primer dilakukan sejak tanggal 1 September 2011 sampai dengan 30 November 2011.

\section{Teknik Pengambilan Sampel}

Sampel yang diambil adalah sampel minimal dilakukan dengan pertimbangan bahwa sampel yang diambil secara representatif dapat mewakili populasi. Oleh karena itu penetapan rumus ukuran sampel dengan presisi (tingkat kesalahan) $10 \%$ dapat dituliskan (Yamane 1979) sebagai berikut :

$$
\mathrm{n}=\frac{\mathrm{N}}{\mathrm{N}(\mathrm{d})^{2}+1}
$$

dimana $\mathrm{n}$ adalah jumlah sampel minima, $\mathrm{N}$ adalah jumlah populasi, dadalah presisi ditetapkan 10 persen yang merupakan tingkat penyimpangan dari karakteristik sampel terhadap populasi, jumlah sampel dalam penelitian adalah 117 responden peternak sapi potong yang dipilih secara purposive random sampling dari 297 kepala keluarga penggaduh ternak sapi potong, pengukuran terhadap jumlah penguasaan ternak didasarkan pada ukuran unit ternak (UT) untuk memperoleh bobot kualitas standard maka penguasaan ternak sapi berumur 1-12 bulan diberikan bobot nilai 0,25 UT setara dengan seekor sapi dewasa dengan bobot nilai $1 \mathrm{UT}$, sedangkan yang berumur $>1 \mathrm{~s} / \mathrm{d} 2$ tahun mempunyai bobot nilai 0,5 UT. Pengumpulan data primer dilakukan tanggal 1 September sampai 30 November 2011. 


\section{Metode Pengambilan Data}

Data primer diambil berupa penguasaan lahan, usia peternak, pendidikan formal, jumlah anggota rumahtangga, jumlah pengusaan ternak sapi potong, curahan waktu bekerja pada usaha sapi potong dan usahatani non sapi potong, teknik pengumpulan data dilakukan dengan teknik survey dengan panduan kuisioner dan wawancara secara mendalam.

\section{Metode Analisis Data}

Analisis dilakukan dengan pengelompokan berdasarkan skala usaha yakni penguasaan ternak sapi potong pada skala I (< 4 UT), skala II (4-6 UT) dan skala III ( $>$ 6UT), diperoleh jumlah responden masing-masing skala usaha yakni 56 responden, 33 responden dan 29 responden, yang dilakukan dengan pendekatan model ekonometrika model ekonomi rumahtangga dan dibangun menggunakan persamaan simultan, menggunakan metode Two Stage Least Square (2SLS), dengan alat bantu program Statistikal Analysis System (SAS) versi 9.1. Model divalidasi dengan menggunakan kriteria Theil's Inequality Coeficient (Greene,2003) untuk simulasi peningkatan jumlah penguasaan ternak sapi induk sebesar $50 \%$ didasarkan pada kapasitas tampung wilayah, dan diperoleh model ekonomi rumahtangga adalah :

Curahan Tenaga Kerja keluarga pada usaha sapi potong:

CTUSP $=$ ao + a1 PTSP + a2 JRUP + a3SPSP $+\mu_{1} \ldots \ldots \ldots \ldots \ldots \ldots \ldots \ldots \ldots \ldots \ldots \ldots \ldots \ldots . . .(1)$

Curahan Tenaga Kerja Non Usaha Sapi Potong:

CTUNSP $=\mathrm{b} 0+\mathrm{b} 1 \mathrm{LKL}+\mathrm{b} 2 \mathrm{PDF}+\mu_{2}$

Keterangan : CTUSP adalah curahan tenaga kerja usaha sapi potong (JKSP/thn /responden), CTUNSP adalah curahan tenaga kerja non usaha sapi potong (JKSP /thn/responden), PTSP adalah produksi ternak sapi potong (UT/tahun/responden), JRUP adalah jumlah anggota rumahtangga usia produktif (Orang), PDF adalah pendidikan formal (Tahun), SPSP adalah Sistim Pemeliharaan Sapi Potong (1 = ternak sapi diikat dan $0=$ dilepas di padang penggembalaan).

\section{HASIL DAN PEMBAHASAN}

\section{Gambaran Umum Daerah Penelitian}

Kecamatan Amanuban Selatan secara geografis berbukit-bukit dan bergununggunung, dengan kemiringan 5-50\% dan jenis tanah adalah formasi batu gamping topografi terdiri dari dataran rendah dan bukit, yang terletak pada ketinggian 0 sampai dengan 200 meter diatas permukaan laut dengan luas wilayah sebesar $292 \mathrm{Km}^{2}$, memiliki jumlah desa sebanyak 10 desa, dengan suhu antara $23^{0} \mathrm{C}-27^{\circ} \mathrm{C}$, dan memiliki curah hujan antara 600 sampai dengan 700 milimeter/tahun.

\section{Curahan Tenaga Kerja}

Curahan tenaga kerja adalah waktu yang digunakan dalam aktifitas usahatani dalam hal ini dihitung jam kerja dalam satu tahun, dengan efektifitas kerja dalam satu hari adalah 5 jam dan dalam satu minggu menggunakan 6 hari kerja, Curahan tenaga kerja pada rumahtangga peternak sapi potong di identifikasikan menjadi 2 (dua) kelompok yaitu curahan tenaga kerja pada usaha sapi potong dan curahan tenaga kerja pada usahatani non sapi potong.

Rataan jam kerja pada usaha sapi potong oleh rumahtangga pada skala I,II dan III masing- masing adalah 123,23 JKSP/tahun/responden, 241,25 JKSP/tahun/ responden, 283,52 JKSP/tahun/responden, hasil generalisasikan curahan tenaga kerja pada usaha sapi potong adalah 195,24 $\mathrm{JKSP} /$ thn/responden. Rataan jam kerja pada usahatani non sapi potong oleh rumahtangga pada skala I,II dan III masing- masing adalah 375,91 JKSP/tahun/responden, 592,59 JKSP/tahun/ responden, 560,90 $\mathrm{JKSP} /$ tahun/responden, dan diperoleh rataan curahan tenaga kerja usahatani non sapi potong adalah 481,05 JKSP/thn/responden. 
Gambar 1 menunjukkan bahwa pada skala III curahan tenaga kerja usaha sapi potong semakin berkurang, sedangkan jumlah penguasaan ternak semakin banyak seharusnya lebih besar waktu kerja yang dicurahkan, hal ini dapat dijelaskan dengan fenomena yang terjadi yakni pada skala usaha ini telah mengupah tenaga kerja (upah yang diberikan berupa anak sapi yang dibayarkan setahun sekali) untuk mengembalakan ternak sapi dipadang dan memasukkan pada sore hari sehingga mengurangi waktu kerja pada usaha sapi potong, dan waktu yang tersisa dapat dimanfaatkan untuk istirahat dan waktu senggang/santai (leisure).

Hasil analisis rataan curahan tenaga kerja tersebut diatas pada masing- masing skala usaha, apabila dilakukan transformasi kebutuhan waktu bekerja untuk satu unit ternak maka dilakukan pembagian rataan jam kerja dengan jumlah unit ternak pada masing-masing skala usaha, sehingga diperoleh waktu bekerja yang dibutuhkan bagi setiap unit ternap pada skala I, II dan III, adalah masing- masing sebesar 51,78 JKSP/UT/Tahun, 48,06 JKSP/UT/Tahun dan 24,85 JKSP/UT/Tahun, apabila digeneralisasikan maka diperoleh waktu bekerja yang dibutuhkan untuk dicurahkan pada satu unit sapi potong di wilayah penelitian adalah sebesar 36,56 JKSP/UT/Tahun.

Tingkat penyerapan tenaga kerja pada usaha sapi potong yang dihitung dari total curahan tenaga kerja oleh rumahtangga pada usahatani yakni skala I,II dan III, masingmasing adalah 24,69\%, 28,93 \%, dan $33,58 \%$, rendahnya penyerapan tenaga kerja pada skala I disebabkan karena jumlah unit ternak yang dimiliki masih sedikit, sehingga pada skala usaha ini berusaha untuk meningkatkan tenaga kerja pada usaha non sapi potong guna meningkatkan pendapatan rumahtangganya hal ini sejalan dengan Skoufias (1994) yang membagi dua tahap dalam penggunaan tenaga kerja yakni tahap pertama keputusan rumahtangga tani dengan penggunaan jumlah tenaga kerja untuk memperoleh keuntungan maksimum, tahap kedua yang dirasakan atas keputusan tahap pertama, petani memutuskan beberapa penggunaan tenaga kerjanya dalam usahataninya dengan upah yang terjadi dipasar.

Apabila digeneralisasikan maka tingkat penyerapan tenaga kerja pada usaha ternak sapi potong mencapai 28,87 \% dibandingkan dengan curahan tenaga kerja pada usahatani non sapi potong, hal ini dapat dijelaskan berdasarkan jumlah rumahtangga yang mengikat ternak sebanyak 21 rumahtangga (17,95 \%), sedangkan sisanya sebesar 82,05 \% menggembalakan ternak di padang penggembalaan.

\section{Hasil Estimasi Model Ekonomi Rumah Tangga Peternak Sapi Potong}

\section{Curahan Tenaga Kerja Keluarga Pada Usaha Sapi Potong}

Curahan tenaga kerja usaha sapi potong merupakan alokasi waktu kerja rumahtangga untuk melakukan kegiatan produktif pada usaha sapi potong. Curahan tenaga kerja usaha sapi potong oleh rumahtangga dipengaruhi oleh jumlah ternak sapi potong, jumlah anggota rumahtangga usia produktif dan sistim pemeliharaan ternak, dengan hasil pengujian pada Tabel 1.

Dengan persamaan CTUSP = 128,7019 + 15,0851PTSP - 14,7417JRUP + 140,6368SPSP hasil perhitungan statistik menunjukkan bahwa secara simultan (bersama-sama) curahan tenaga kerja usaha sapi potong dipengaruhi oleh penguasaan ternak sapi potong, jumlah rumahtangga usia produktif dan sistim pemeliharaan sapi potong sebesar 56,17 \%, sedangkan sisanya sebesar 43,83 \% merupakan faktor lain yang tidak terdapat dalam model, seperti pendapatan yang diperoleh, karakter individu dan keluarga peternak, karakteristik usahatani, harga ternak sapi potong, lingkungan dan lain-lain.

Rendahnya nilai $\mathrm{R}$ square disebabkan karakteristik rumah tangga yang mengusahakan ternak masih bersifat tradisional, rendahnya pengetahuan peternak mengenai manajemen usaha ternak sapi 


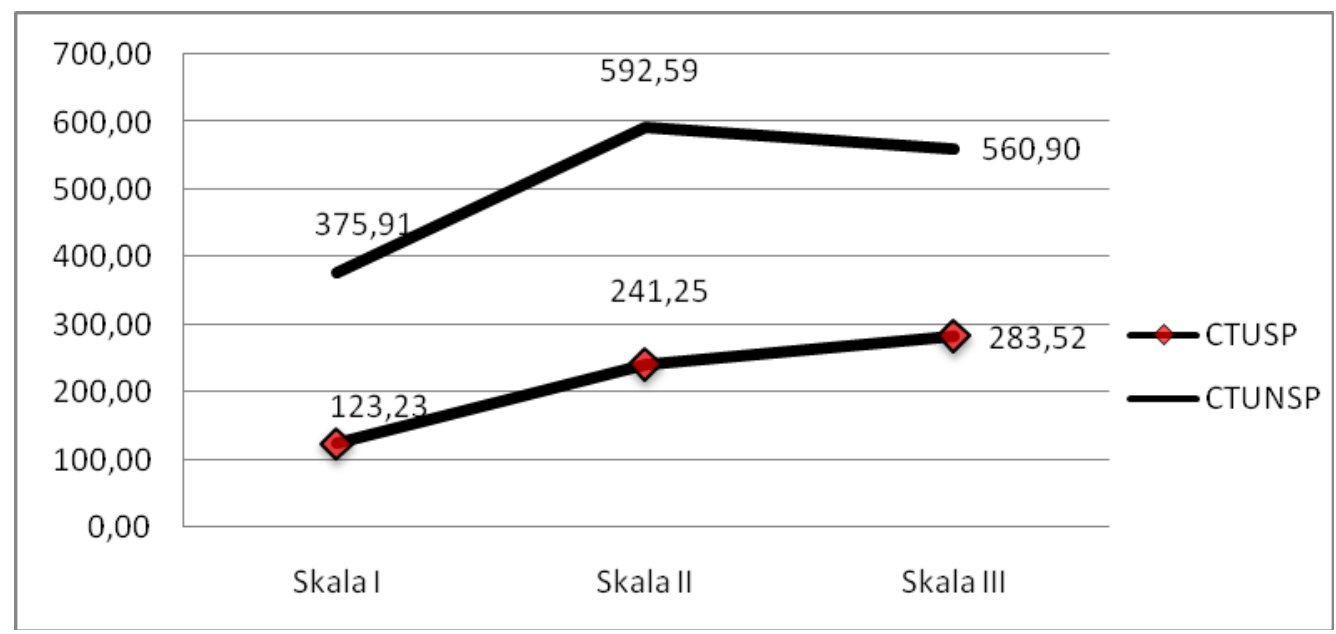

Gambar 1. Rataan Curahan Tenaga Kerja rumahtangga peternak sapi potong (JKSP/tahun/responden)

Keterangan :

CTUSP: Curahan Tenaga Kerja Usaha Sapi Potong (JKSP/tahun /responden) CTUNSP Curahan Tenaga Kejra Usahatani Non Sapi Potong (JKSP/tahun /responden)

Tabel 1. Hasil Estimasi Curahan Tenaga Kerja Keluarga pada Usaha Sapi Potong (CTUSP)

\begin{tabular}{lcccccc}
\hline Variabel & $\begin{array}{c}\text { Parameter } \\
\text { Estimasi }\end{array}$ & Standard Error & $t_{\text {hitung }}$ & Prob t & Prob F & Rsquare \\
& 128,7019 & 21,21 & & & $<0,0001$ & 0,56173 \\
Intercept & 15,0851 & 1,55 & 9,72 & $0,000^{(* *)}$ & & \\
PTSP & $-14,7417$ & 6,96 & $-2,12$ & $0,034^{(*)}$ & & \\
JRUP & 140,6368 & 20,04 & 7,02 & $0,000^{(* *)}$ & & \\
SPSP & & & & \\
\hline
\end{tabular}

potong, penguasaan ternak sapi potong yang tidak merata, kondisi alam dengan musim kemarau yang panjang mengakibatkan krisis pakan dimusim kemarau, kesulitan penyediaan air minum ternak pada musim kekeringan dan sebagainya.

Hubungan Curahan Tenaga Kerja Usaha Sapi Potong dengan Penguasaan Ternak Sapi Potong. Hasil pengujian secara parsial menunjukkan bahwa penguasaan sapi potong berpengaruh positif terhadap curahan tenaga kerja usaha sapi potong dengan parameter sebesar 15,0851 dan secara statistik berpengaruh sangat nyata dengan Probabilitas <0,0001 dan $t_{\text {hitung }}$ sebesar 9,72. Nilai parameter bertanda positif mengindikasikan bahwa hubungan antara penguasaan ternak sapi dan curahan tenaga kerja usaha sapi potong adalah positif dan searah dengan keterkaitan yang sangat kuat artinya semakin meningkat penguasaan ternak sapi potong semakin besar curahan tenaga kerja usaha sapi potong

Hasil yang diperoleh menunjukkan perbedaan dengan Priyanti et al. (2006) yang memperoleh hasil estimasi yang negatif pada curahan tenaga kerja dalam keluarga usaha sapi potong yakni sebesar -1,485646 dan secara statistik berpengaruh nyata, hal ini karena terdapat variasi jumlah penguasaan ternak setiap rumahtangga, faktor sosial ekonomi masyarakat, kultur budaya masyarakat setempat dan sebagainya yang terdapat diwilayah penelitian.

Hubungan Curahan Tenaga Kerja Usaha Sapi Potong dengan Jumlah Rumah Tangga Usia Produktif. Jumlah anggota rumahtangga usia produktif 
berpengaruh negatif terhadap curahan tenaga kerja usaha sapi potong dengan parameter sebesar -14,7417 dan secara statistik berpengaruh nyata pada selang uji 0,034 dan

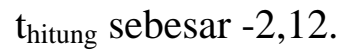

Nilai parameter bertanda negatif mengartikan bahwa hubungan antara curahan tenaga kerja usaha sapi potong dengan jumlah anggota rumahtangga usia produktif berbanding terbalik dan tidak searah yang artinya bahwa semakin meningkat jumlah anggota rumahtangga usia produktif akan menurunkan curahan tenaga kerja pada usaha sapi potong, Jumlah anggota rumahtangga usia produktif berpengaruh negatif terhadap curahan tenaga kerja usaha sapi potong disebabkan karena karakteristik pemeliharaan ternak sapi potong, komposisi dan jumlah anggota rumahtangga, tingkat pendidikan akan menentukan seberapa besar tenaga kerja yang akan dicurahkan pada usaha sapi potong, faktor lainnya yang mempengaruhi curahan tenaga kerja adalah penduduk yang jarang, terdapat hamparan kosong akan mendorong peternak untuk melepaskan ternak sapi dipadang penggembalaan sehingga tidak membutuhkan terlampau banyak jumlah anggota rumahtangga usia produktif yang mencurahkan tenaga kerja pada usaha sapi potong.

\section{Hubungan Curahan Tenaga Kerja} Usaha Sapi Potong dengan Sistim Pemeliharaan Ternak Sapi Potong. Hasil pengujian parsial diperoleh sistim pemeliharaan sapi potong berkorelasi positif terhadap curahan tenaga kerja usaha sapi potong dengan parameter sebesar 140,6368 dan secara statistik berpengaruh sangat nyata pada selang uji 0,0001 pada $t_{\text {hitung }}$ sebesar 7,02, hal ini berarti bahwa hubungan antara curahan tenaga kerja usia produktif dan sistim pemeliharaan sapi potong positif dan searah artinya bahwa semakin baik sistim pemeliharaan ternak sapi potong akan semakin meningkat curahan tenaga kerja usaha sapi potong.
Nilai estimasi menggambarkan bahwa apabila sistim pemeliharaan sapi potong dirubah dari sistim lepas menjadi sistim ikat (SPSP=1) maka waktu kerja pada curahan tenaga kerja usaha sapi potong akan mengalami peningkatan sebesar 140,64 JKSP/Tahun/ responden. Sistim pemeliharaan ternak sapi potong berpengaruh sangat nyata terhadap curahan tenaga kerja usaha sapi potong karena sistim pemeliharaan merupakan faktor utama yang menentukan besarnya jumlah pemanfaatan waktu kerja yang akan dicurahkan pada usaha sapi potong oleh rumahtangga.

Fenomena yang terjadi diwilayah ini sistim pemeliharaan ternak masih dilakukan secara tradisional yaitu ternak sapi potong dilepas dipadang penggembalaan dan dilakukan pengontrolan secara periodik untuk dilakukan perhitungan perkembangan populasinya, sistim ini menguntungkan bagi peternak dalam mencurahkan tenaga kerja pada usaha sapi potong. Widodo (2008) mengungkapkan bahwa pola pemeliharaan ekstensif yang terjadi didaerah yang jarang penduduk yang melepaskan ternaknya dipadang rumput dipilih dengan pertimbangan efisiensi tenaga kerja.

\section{Curahan Tenaga Kerja Usahatani Non Sapi Potong (CTUNSP)}

Curahan Tenaga kerja usahatani non sapi potong merupakan curahan tenaga kerja keluarga pada usahatani selain usaha sapi potong oleh rumahtangga peternak dalam satu tahun (on farm) (Tabel 2) dengan persamaan:

\section{CTUNSP $=213,0716+286,8873 L K L-$ 8,27116PDF}

Hasil perhitungan statistik menjelaskan bahwa secara simultan luas kepemilikan lahan dan pendidikan formal peternak berpengaruh terhadap curahan tenaga kerja usahatani non sapi potong sebesar 53,90 \% sedangkan sisanya sebesar 46,10 \% merupakan faktor lain yang tidak terdapat dalam model seperti jenis tanaman, penerapan teknologi usahatani dan lain-lain. 
Tabel 2. Hasil Estimasi Parameter Model Curahan Tenaga Kerja Usahatani Non Sapi Potong

\begin{tabular}{lcccccc}
\hline \multicolumn{1}{c}{ Variabel } & $\begin{array}{c}\text { Parameter } \\
\text { Estimasi }\end{array}$ & $\begin{array}{c}\text { Standard } \\
\text { Error }\end{array}$ & thitung $_{\text {Prob t }}$ & Prob F & R.Square \\
\hline Intercept & 213,0716 & 68,85 & & & $<0,0001$ & 0,53902 \\
LKL & 286,8873 & 37,81 & 7,59 & $0,000^{(* *)}$ & & \\
PDF & $-8,27116$ & 1,15 & $-7,21$ & $0,000^{(* *)}$ & & \\
\hline
\end{tabular}

Hubungan Curahan Tenaga Kerja Usahatani Non Sapi Potong dengan Luas Kepemilikan Lahan. Hasil analsis secara parsial diperoleh luas kepemilikan lahan berkorelasi positif terhadap curahan tenaga kerja usahatani non sapi potong dengan parameter sebesar 286,8873 dan secara statistik berpengaruh sangat nyata pada selang uji 0,0001, dan thitung sebesar 7,59, hal ini mengindikasikan bahwa hubungan antara curahan tenaga kerja usahatani non sapi potong dengan luas kepemilikan lahan adalah positif dan searah artinya bahwa apabila luas kepemilikan lahan meningkat akan mempengaruhi peningkatan curahan tenaga kerja usahatani non sapi potong.

Nilai estimasi sebesar 286,89 JKSP/Tahun/ responden, mengimplikasikan bahwa optimalisasi tenaga kerja oleh rumahtangga meningkat melalui curahan waktu berkerja yang lebih lama pada lahan usahatani yang semakin diperluas, hal ini dimungkinkan karena kesempatan rumahtangga untuk memanfaatkan usahatani hanya terjadi satu tahun sekali, sehingga harapan petani terhadap hasil usahatani yang diperoleh terhadap kebutuhan keluarga dalam rumahtangga untuk masa satu tahun relatif dapat terpenuhi, selain itu kesempatan melakukan keragaman usahatani pada lahan usahatani yang lebih luas akan lebih banyak dibandingkan kepemilikan lahan usahatani yang sempit.

Hasil penelitian yang diperoleh bertentangan dengan hasil penelitian Bardhan (1979) di India dimana ditemukan hubungan yang signifikan antara jumlah anggota dewasa yang bekerja disektor pertanian dengan curahan jam kerjanya sedangkan variabel luas lahan mempunyai hubungan yang negatif dengan curahan kerja anggota keluarga usia dewasa. Hal ini disebabkan karena karakteristik mata pencaharian penduduk yang sebagian besar petani diwilayah penelitian dengan ketersediaan luasan kepemilikan lahan yang terbatas, menjadikan lahan usahatani sebagai sumber pendapatan utama dan konsumsi bagi keluarga. Hasil empirik sering menunjukkan bahwa luas lahan mempunyai korelasi positif terhadap tenaga kerja yang diminta dan biasanya luas lahan sempit sering menggunakan input tenaga kerja yang lebih besar Walker and Ryan (1990) dalam Sukiyono et al. (2004).

Hubungan Curahan Tenaga Kerja Usahatani Non Sapi Potong dengan Pendidikan Formal. Hasil pengujian secara parsial pendidikan formal berpengaruh negatif terhadap curahan tenaga kerja usahatani non sapi potong dengan parameter sebesar -8,27116 dan secara statistik berpengaruh sangat nyata pada selang uji

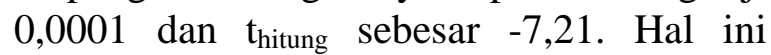
menunjukkan bahwa hubungan antara curahan tenaga kerja usahatani non sapi potong dan pendidikan formal berbanding terbalik dan tidak searah, yang artinya bahwa semakin tinggi tingkat pendidikan semakin rendah curahan tenaga kerja usahatani non sapi potong.

Pendidikan semakin tinggi seharusnya semakin baik dalam pengelolaan usahatani sehingga semakin efisien alokasi waktu kerja namun pada kenyataan semakin tinggi tingkat pendidikan akan semakin enggan untuk bekerja pada lahan usahatani, hal ini karena pola usahatani yang bersifat ketergantungan pada alam sehingga membentuk pola tanam yang hanya dilakukan satu kali dalam setahun, perolehan 
Tabel 3. Analisis Kepadatan Ternak dan daya dukung pakan di Wilayah Kecamatan Amanuban Selatan

\begin{tabular}{lrc}
\hline \multicolumn{1}{c}{ Uraian } & Nilai & Keterangan \\
\hline Penguasaan sapi potong (ST) & 3,07 & Rendah \\
Indeks Daya Dukung wilayah (IDD) & 2,88 & Aman \\
Kepadatan Ekonomi (UT/Jiwa) & 288,43 & Padat \\
Kepadatan Usahatani (UT/Ha) & 1,20 & Padat \\
Kepadatan Wilayah (UT/KM ${ }^{2}$ ) & 24,84 & Sedang \\
Koefisien Penambah (UT) & 12.240 & \\
\hline
\end{tabular}

Sumber : Data diolah (2012)

Tabel 4. Peningkatan Jumlah Ternak Sapi Induk Terhadap Ekonomi Rumahtangga Penggaduh Sebesar $50 \%$

\begin{tabular}{lrrc}
\hline Variabel Endogen & Simulasi Dasar & Simulasi Skenario & Perubahan \% \\
\hline CTUSP & 195,20 & 233,00 & 19,36 \\
PTSP & 5,32 & 7,82 & 47,01 \\
SSP & 1288162,00 & 1448844,00 & 12,74 \\
PRT & 14912757,00 & 15073428,00 & 1,08 \\
KPP & 2718188,00 & 2726555,00 & 0,31 \\
KPNP & 2181419,00 & 2188353,00 & 0,32 \\
TPKP & 4899607,00 & 4914908,00 & 0,31 \\
TPR & 12680960,00 & 12696259,00 & 0,12 \\
\hline
\end{tabular}

Sumber : Analisis Data Primer (2012)

hasil panen yang tidak menentu, fluktuasi harga pasar terhadap hasil-hasil pertanian serta usahatani yang hanya bersifat subsistem mengakibatkan semakin tinggi pendidikan formal peternak maka ada kecenderungan untuk mencurahkan tenaga kerjanya pada alternatif lain selain usahatani untuk memperoleh pendapatan. Ellis (1989) dalam teory Chayanov, dampak masuknya aspek biaya opportunitas tenaga kerja adalah bahwa alokasi tenaga kerja rumahtangga tidak lagi ditentukan oleh struktur keluaraga tetapi sudah lebih berorientasi pasar.

\section{Keterkaitan Peningkatan Jumlah Ternak Sapi Induk Terhadap Ekonomi Peternak Sapi Potong}

Hasil analisis daya dukung menunjukkan peluang yang cukup besar dalam usaha pengembangan ternak sapi potong. Dengan indeks daya dukung yang masih aman sehingga masih dibutuhkan penamabahan ternak diwilayah ini sebesar 12.240 unit ternak (Tabel 3). Upaya peningkatan jumlah penguasaan ternak dapat dilakukan dengan berbagai cara yakni membeli ternak sapi di pasar, melakukan kredit dengan bunga rendah, maupun perolehan bantuan pemerintah, untuk itu dilakukan simulasi peningkatan jumlah ternak sapi potong sebesar $50 \%$ terhadap ekonomi rumahtangga penggaduh (Tabel 4).

Hasil simulasi menunjukkan peningkatan jumlah penguasaan ternak sapi induk sebesar 50 \% maka akan meningkatkan curahan tenaga kerja pada usaha sapi potong sebesar 19,36 \%, produksi ternak meningkat 47,01 \%, dan surplus usaha sapi potong mengalami peningkatan sebesar 12,74 \%, hal ini berarti bahwa peningkatan penguasaan ternak sapi potong oleh rumahtangga penggaduh memberikan dampak yang positif terhadap perkembangan 
ekonomi rumahtangga penggaduh karena usaha sapi potong selain dianggap sebagai tabungan yang sewaktu-waktu dapat dimanfaatkan oleh rumahtangga penggaduh untuk memenuhi kebutuhan biaya yang besar, usaha sapi potong juga sangat cocok untuk dikembangkan diwilayah ini, yang didukung oleh sumber ketersediaan pakan yang masih belum termanfaatkan secara maksimal terutama pada musim penghujan.

\section{KESIMPULAN}

Alokasi curahan tenaga kerja pada usaha sapi potong adalah sebesar 195,24 $\mathrm{JKSP} /$ tahun/responden, yang dipenga-ruhi jumlah penguasaan ternak sapi potong, jumlah anggota rumahtangga usia produktif dan sistim pemeliharaan ternak sapi potong, sedangkan usahatani non sapi potong adalah sebesar 481,05 JKSP/tahun/ responden, yang dipengaruhi oleh luas kepemilikan lahan dan pendidikan formal peternak. Hasil simulasi peningkatan jumlah ternak sapi induk dalam rumahtangga penggaduh sebesar $50 \%$ dapat meningkatkan waktu curahan tenaga kerja usaha sapi potong, produksi ternak dan surplus usaha sapi potong.

\section{DAFTAR PUSTAKA}

Anonim. 2010. Laporan Tahunan Unit Pembibitan Ternak dan Produksi Makanan Ternak, Dinas Peternakan Provinsi NTT.

Bardhan, P.K., 1979. Labor Supply Fuction in A

Poor Agrarian Economy, The America Economic Review.
Ellis, F., 1989. Peasant Economics, Farm Household And Agrarian Development, Cambride University Press New York.

Greene, W.H. 2003. Econometric Analysis, Fourth Edition, Prentice Hall.

Priyanti, A., Sinaga, B. M., dan Syaukur, Y. 2009. Tingkat Adopsi Program Sistim Integrasi Padi-Ternak (SIPT), Balai Besar Pengkajian dan Pengembangan Teknologi Pertanian Badan Penelitian dan Pengembangan Pertanian Departemen Pertanian; Journal Pengkajian dan Pengembangan Teknologi Pertanian Vol. 12 No.1; 21-30.

Skoufias, E. 1994. Using Shadow Wages to Estimate Labor Supplay of Agriculture Houshold. Amer. Journal of Agriculture Economics 76:215-227.

Soekartawi., Soeharjo, A., Dillon, J. L., Hardaker, J.B., 1986. Ilmu Usahatani dan Penelitian untuk pengembangan Petani Kecil, Penerbit Universitas Indonesia (Department Of Education and Culture Directorate General of Higher EducationAustralian Universities International Development Program).

Sukiyono,K. dan Sriyono, 2004 Kontribusi Penawaran Tenaga Kerja Anggota Rumahtangga Perkebunan Kelapa Sawit, Jurnal Ilmu-Ilmu Pertanian Indonesia, 7: 111-118.

Widodo, M. W., 2008 Perkembangan Ekonomi dan Perencanaan Usahatani di Indonesia. Ed. 1 Cet. 1

Yamane, 1979. Matematics for Economics and Elementary. Engelwood Cliff New Jersey. 